\title{
Effects of Bungur Leaves (Lagerstroemia speciose (L.) Pres.) on Malondialdehyde and Blood Glucose Levels in Hyperglycemic Mice
}

Rika Sari Dewi*, Lestari Rahayu, Ni Made Dwi Sandhiutami, Oci Purnama Sari

Faculty of Pharmacy, University of Pancasila, Jakarta, INDONESIA.

\begin{abstract}
Background: Bungur leaves have saponins, tannins, ellagitannin and flavonoids that could function as antioxidant and antihyperglycemic. Bungur leaves also consumed in Indonesia people for their diabetes treatment for a long time. Objective: The aim of this research is to know bungur leaves as antioxidant and antihyperglycemic so that can be used in the alternative therapy of diabetes mellitus. Methods: Mice were made hyperglycemic using alloxan, except normal group. The study was carried out using 30 mice divided into 6 groups: normal group, negative group, positive group, and treated group with 3 dose variation from bungur leaves decoction and taken the data on day 0,5 , and 19. Results: The result in normal group, negative group (alloxan), positive group (glibenclamide), treatments group which given by doses $1.6 \mathrm{~g} / \mathrm{kgBW}, 3.2 \mathrm{~g} / \mathrm{kgBW}, 6.4 \mathrm{~g} / \mathrm{kgBW}$ of MDA levels respectively $0.6993 \mathrm{nmol} / \mathrm{mL} ; 4.1953 \mathrm{nmol} / \mathrm{mL} ; 0.8462 \mathrm{nmol} / \mathrm{mL} ; 4.2873$ $\mathrm{nmol} / \mathrm{mL} ; 3.3700 \mathrm{nmol} / \mathrm{mL} ; 2.0670 \mathrm{nmol} / \mathrm{mL}$ while blood glucose levels on 19th day respectively $107.6 \mathrm{mg} / \mathrm{dL} ; 149.2 \mathrm{mg} / \mathrm{dL} ; 104 \mathrm{mg} / \mathrm{dL} ; 93 \mathrm{mg} / \mathrm{dL}$; $109.6 \mathrm{mg} / \mathrm{dL} ; 104 \mathrm{mg} / \mathrm{dL}$. MDA levels on $6.4 \mathrm{~g} / \mathrm{kgBW}$ and the averages of
\end{abstract}

MDA levels have different significantly with a positive group, while blood glucose levels showed all treatments groups doses has no different significantly with positive group analyzed statistically. Conclusion: Bungur leaves have an effect to decrease MDA levels but not as well as glibenclamide while they have an effect to decrease blood glucose as well as glibenclamide.

Key words: Anti hyperglycemic, Antioxidant, Bungur, Glibenclamide, Hyperglycemic mice.

\section{Correspondence}

Rika Sari Dewi, Faculty of Pharmacy, University of Pancasila, Jakarta, INDONESIA. Phone:+62 81221709700

Email: rika.ffup@gmail.com

DOI: 10.5530/jyp.2018.2s.25

\section{INTRODUCTION}

Free radicals are compounds that do not have electron pairs so have a tendency to pair with other compounds. Free radicals also cause the degenerative diseases such as heart disease, cancer, and diabetes mellitus. Diabetes mellitus is a condition where blood glucose levels are above the normal levels (hyperglycemia). Hyperglycemia can lead to the production of Reactive Oxygen Species (ROS) or free radicals are excessive and will trigger oxidative stress. ${ }^{1}$ This study aimed to obtain active compounds derived from plants that can act as antihyperglycemic and antioxidants that can be used in the alternative therapy of diabetes mellitus. Bungur leaves are one of the plants that long used and utilized for the treatment of diabetes mellitus in Indonesia. The content of tannins, elagitanins, saponins, and flavonoids empirically can act against free radicals in the body. In this study, bungur leaves decoction has been testing its antioxidant in vivo by looking at its ability to reduce levels of malondialdehyde and antihyperglycemic activity by looking at the parameters of blood glucose in mice that were previously inducted by alloxan.

\section{MATERIALS AND METHODS}

\section{Materials and Instrumentations}

Bungur (Lagerstroemia speciosa (L.) Pers.) leaves, male mice with DDY strain, anticoagulant heparin, alloxan tetrahydrate, Glibenclamide.

\section{Plant materials}

Bungur leaves were determined before use at Herbarium Bogoriense, Biology Research Center- LIPI, Bogor, Indonesia.

\section{Preparation of experimental animals}

The experimental animals used were mice (Mus musculus), male type, DDY strain aged 8-12 weeks with 20-30 g weight. Before being used in the experiment, all the mice were acclimatized for one week in advance.

\section{Making bungur leaves decoction}

Bungur leaves were weighed $80 \mathrm{~g}$, then washed clean. Then boil the bungur leaves with $600 \mathrm{~mL}$ of water until boiling until the volume becomes $200 \mathrm{~mL}$.

\section{Effect of bungur leaves decoction to levels of malondialdehyde and blood glucose test}

After the mice were acclimatized, mice were divided into six groups each group consisting of 5 mice. See Table 1.

Mice were made hyperglycemic with Alloxan intraperitoneally for 3 days, except normal controls. Tests carried out simultaneously to obtain malondialdehyde levels and blood glucose on day 0, 5 and 19.

To get MDA, blood placed in centrifuge tubes that had been given anticoagulant heparin, the blood obtained centrifuged at $3000 \mathrm{rpm}$ for $10 \mathrm{~min}$. Once separated the top layer (plasma) taken as many as $200 \mathrm{~mL}$ added $1.0 \mathrm{ml}$ trichloroacetic (TCA) $20 \%$ and $2 \mathrm{ml}$ tiobarbiturat acid (TBA) $0.67 \%$. The solution is mixed with homogeneous heat in water for $10 \mathrm{~min}$. After that centrifuged at $3000 \mathrm{rpm}$ for $10 \mathrm{~min}$. The pink filtrate measured the absorption wavelength of $530 \mathrm{~nm}$ using a UV-VIS spectrophotometer. MDA levels are calculated using a standard TEP curve. 
Table 1: Distribution of experimental animal group.

\begin{tabular}{cc} 
Group & Treatment \\
\hline I & Normal control \\
II & Negative control, aquadest \\
III & Positive control with administration of Glibenclamide dose \\
& $5 \mathrm{mg} / \mathrm{kg} \mathrm{BW}$ \\
IV & Decoction of bungur leaves dose $1.6 \mathrm{~g} / \mathrm{kg} \mathrm{BW}$ \\
V & Decoction of bungur leaves dose $3.2 \mathrm{~g} / \mathrm{kg} \mathrm{BW}$ \\
VI & Decoction of bungur leaves dose $6.4 \mathrm{~g} / \mathrm{kg} \mathrm{BW}$ \\
\hline
\end{tabular}

Table 2: The averages of MDA plasma levels on mice (nmol/mL).

\begin{tabular}{cccc}
\hline Group & Day-0 & Day-5 & Day-19 \\
\hline I & 0.8338 & 0.8188 & 0.6993 \\
II & 0.8204 & 4.7802 & 4.1953 \\
III & 0.8007 & 4.3882 & 0.8462 \\
IV & 0.7593 & 4.5057 & 4.2873 \\
V & 0.8103 & 4.6457 & 3.3700 \\
VI & 0.8175 & 4.5635 & 2.0670 \\
\hline
\end{tabular}

To get blood glucose levels, measure mice blood glucose levels using glucometer. When the blood glucose level is measured, the mice should be fast first for about $16 \mathrm{~h}$. Measurement of MDA and blood glucose in mice: before administration of Alloxan (day 0), after 5 days of administration of Alloxan (at the time of a hyperglycemic condition/day 5) and after offering the treatment (19th day). The data have been tested statistically using ANOVA to see whether there is a difference or not.

\section{RESULTS}

\section{Effects of bungur leaves decoction on malondialdehyde levels (MDA)}

In the effectiveness of antioxidant testing, it is known that the levels of MDA in plasma shown in the table. See Table 2.

In the day- 0 , the averages of MDA plasma is $0.7593-0.8338 \mathrm{nmol} / \mathrm{mL}$. After being inducted by alloxan $\left(\right.$ day $\left.-5^{\text {th }}\right)$, that is showed an increase of the MDA by all groups except normal group (group I). It can lead that was redox reaction on $\beta$ pancreatic cells caused by alloxan. The results of that process is dialuric acid, which together with alloxan generates superoxide radical compound. After the mice became hyperglycemic, then the mice were given bungur leaves decoction with 3 variations dose and measured the levels of MDA on day 19.

The results of plasma MDA levels showed an increase of negative group that is the groups of experimental animals induced by alloxan and not receive bungur leaves and glibenclamide. In the positive group and the treatment group given bungur leaves decoction with 3 variations dose there were a decrease of MDA level compare to negative group. It can be interpreted that lipid peroxidation process that occurs in hyperglycemia mice can be prevented by giving glibenclamide and bungur leaves decoction. The average of MDA plasma of each group were shown in Figure 1tB which can show that the treatment group given bungur leaves decoction with $6.4 \mathrm{~g} / \mathrm{kgBW}$ having the lowest MDA level compared to other group. The higher dose of bungur leaves decoction given the greater decrease in MDA levels. The average of $6.4 \mathrm{~g} / \mathrm{kg}$ BW treatment group was 2.067 $\mathrm{nmol} / \mathrm{mL}$ and that were statistically significant differences with positive group, that means a dose of $6.4 \mathrm{~g} / \mathrm{kgBW}$ of bungur leaves decoction

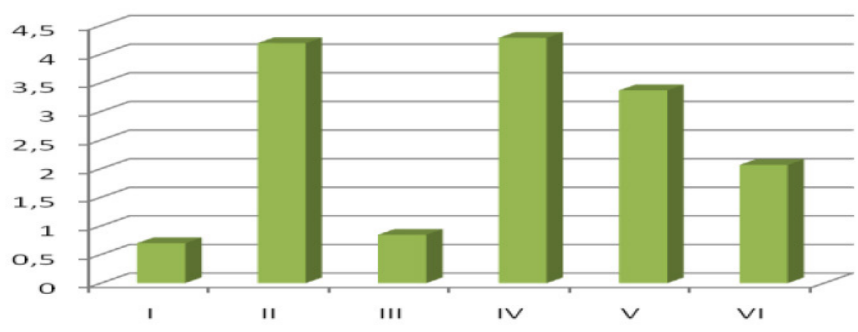

Figure 1: The averages of MDA plasma levels on mice $(\mathrm{nmol} / \mathrm{mL})$.

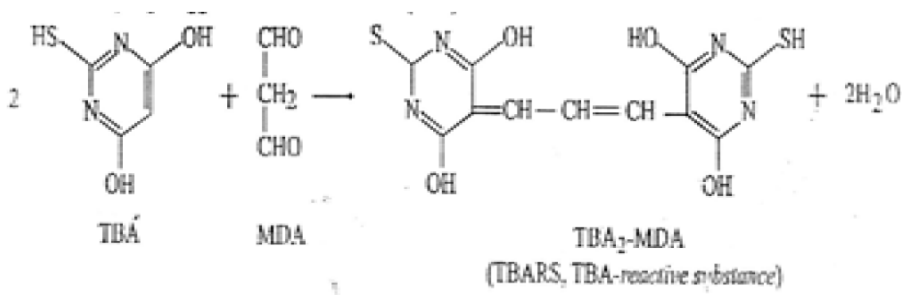

Figure 2: The reaction between MDA and TBA. ${ }^{5}$

Table 3: The averages of mice blood glucose levels ( $\mathrm{mg} / \mathrm{dL})$.

\begin{tabular}{cccc}
\hline Group & Day-0 & Day-5 & Day-19 \\
\hline I & 98.2 & 100.0 & 107.6 \\
II & 96.0 & 158.2 & 149.2 \\
III & 105.4 & 174.6 & 104.0 \\
IV & 108.0 & 172.2 & 93.0 \\
V & 108.6 & 166.4 & 109.6 \\
VI & 108.6 & 167.0 & 104.0 \\
\hline
\end{tabular}

could not be able to decrease the MDA plasma levels as well as the positive group that given glibenclamide.

\section{Effects of bungur leaves decoction on blood glucose levels}

The averages of mice blood glucose levels shown in the table. See Table 3. The average of mice blood glucose levels on day- 0 is $80-118 \mathrm{mg} / \mathrm{dL}$, which is based on the literature that data meets requirements of normal fasting blood glucose levels (70-120 mg/dL). ${ }^{2}$ Based on ANOVA statistical analysis, known that was not significant difference.

Measurement of blood glucose levels on day 5 was done to find whether in groups II, III, IV, V and VI the mice got hyperglycemic after induced by alloxan, by looking at group I as comparator where group I was not induced by alloxan. Blood glucose levels experienced an increase of 142-202 mg/dL. Based on statistical analysis of Mann-Whitney test, known that blood glucose levels of group II, III, IV, V and VI were not significantly different.

Measurement of blood glucose levels on day 19 after the treatment was done to know whether the group of mice given the treatment decreased blood glucose levels or not. From table 3 known that hyperglycemic mice given treatment got decrease blood glucose levels. From ANOVA statistical analysis, there was significance $0.022(\mathrm{p}<0,05)$. This shows that there is a significant difference from blood glucose levels on the day 19th between groups I, II, III, IV, V and VI which means there is a difference between mice treated with mice did not treated. Because there is significant 
Table 4: LSD test of blood glucose levels on day 19.

\begin{tabular}{ccccccc}
\hline Group & I & II & III & IV & V & VI \\
\hline I & & & & & & \\
II & $41.6^{*}$ & & & & & \\
III & 3.6 & $45.2^{*}$ & & & \\
IV & 14.6 & $56.2^{*}$ & 11.0 & & & \\
V & 2.0 & $39.6^{*}$ & 5.6 & 16.6 & & \\
VI & 3.6 & $45.2^{*}$ & 0.0 & 11.0 & 5.6 \\
\hline
\end{tabular}

*There is a significant difference

I: Normal Control; II: Negative Control; III: Positive Control; IV: Dose 1.6 g/kgBW; $\mathrm{V}$ : Dose $3.2 \mathrm{~g} / \mathrm{kgBW}$; VI: Dose $6.4 \mathrm{~g} / \mathrm{kg}$ BW.

difference then analysis continued with LSD test. LSD test results shown in Table 4.

\section{DISCUSSION}

Alloxan is a diabetogenic agent and often used to induce diabetes on experimental animals. Alloxan injection in animals leads to degeneration of $\beta$ pancreatic cells in the islets of Langerhans. The mechanism of action of alloxan begins with the occurrence of redox reactions in alloxan entering to $\beta$ pancreatic cells. Alloxan has high activity against cellular compounds containing $\mathrm{SH}$, reduced glutathione (GSH), cysteine, sulfhydryl protein related compounds (eg, $\mathrm{SH}$-containing enzyme). The result of alloxan reduction process is dialuric acid, then re-oxidation becomes alloxan again continuously. The alloxan and dialuric acid formed generates superoxide radical compounds $(0 \mathrm{z} \bullet)$. Superoxide radicals release ferric ions from ferinitin which then reduces to ferrous ions, and undergoes dismutase into hydrogen peroxide $\left(\mathrm{H}_{2} \mathrm{O}_{2}\right)$. The ferro and $\mathrm{H}_{2} \mathrm{O}_{2}$ ions undergo a redox reaction (Fenton reaction) forming a hydroxyl radical resulting in DNA fragmentation of the nucleus. The fragmentation of nuclear DNA begins with the loss of the DNA proximal chain. The damage sustained so as to stimulate the poly (ADP-ribose) synthetase is involved in DNA repair processes, which then resulted in the depletion of Nicotinamide adenine dinucleotide $(\mathrm{NAD}+)$ intracellular and finally make pancreatic $\beta$ cell death. ${ }^{3}$

The most important components of cell membranes are phospholipids, glycolipids, and cholesterol. The first two components contain unsaturated fatty acids which are particularly vulnerable to free radical attacks, especially hydroxyl radicals that can cause lipid peroxidation chain reactions. The end result of this reaction is the breakdown of fatty acid chains into various compounds that are toxic to the cell, including various aldehydes, such as malondialdehyde (MDA). Malondialdehyde is the product of the lipid peroxidation process of the cell membrane by the reactive oxygen compound resulting in the breakdown of the fatty acid chain by producing malondialdehyde and cell membrane damage. Thus indirectly malondialdehyde can be used to measure lipid peroxidation. ${ }^{4}$

The principle of measurement of MDA with TBA reagent, based on the reaction between one molecules of MDA with two TBA molecules under acidic conditions. The result is a pink and measurable MDA-TBA complex compound at a wavelength of $532 \mathrm{~nm}$. The reaction between MDA and TBA is shown in Figure $2 .^{5}$

The amount of MDA detected illustrates the amount of lipid peroxidation that occurs. The MDA level is calculated by inserting it into the standard TEP standard curve equation. 1, 1, 3, 3-tetraethoxypropane is an MDA precursor which, when hydrolyzed with water, results in MDA. Analysis of free radical levels in this study was done by measuring blood plasma
MDA levels using UV-VIS spectrophotometer. This method is the most method widely used to measure the presence of free radicals and lipid peroxidation because it has a fairly high sensitivity, easy to apply to a variety of samples at different lipid oxidation stage. ${ }^{4}$ Decreased levels of MDA in groups of mice given bungur leaves with 3 variations of dosage due to bungur based on phytochemical screening has saponin, flavonoid, tannin and elegitanin compound which can act as an antioxidant. Flavonoid compounds are a class of secondary antioxidants that can have synergistic effects with primary antioxidants that can increase the effectiveness of primary antioxidant action in the body.

In the test of bungur leaves decoction effect on blood glucose levels, blood glucose levels of mice in group I had average blood glucose levels is normal $107.6 \mathrm{mg} / \mathrm{dL}$. Group II was used as a negative control induced by Alloxan without any treatment to determine the hyperglycemic effect of Aloxan. On the $5^{\text {th }}$ day of group 2 mice experienced an increase in blood glucose level by an average of $158.2 \mathrm{mg} / \mathrm{dL}$ and only slightly decreased by $149.2 \mathrm{mg} / \mathrm{dL}$ on the 19th day. This is caused by the presence of regeneration and neogenesis of pancreatic $\beta$ cells that can happen within 12 days after the use Alloxan, so that after a given Alloxan will be an increase in blood glucose that can be returned normally in a few months. ${ }^{6}$

Group III was used as a positive control induced by Alloxan prior to treatment of the comparative drug Glibenclamide. On day 5, group III mice experienced an average increase in blood glucose of $174.6 \mathrm{mg} / \mathrm{dL}$, then after treatment with Glibenclamide for 14 days, mean blood glucose levels decreased to $104 \mathrm{mg} / \mathrm{dL}$. This indicates that Glibenclamide is an effective antihyperglycemic in reducing glucose levels.

Groups IV, V and VI were used as the Alloxan-induced group before treatment, after the mice had hyperglycemic conditions, on the 5th day the mice were given the treatment of the bungur decoction with variation dose $1.6 \mathrm{~g} / \mathrm{kg} \mathrm{BB}, 3.2 \mathrm{~g} / \mathrm{kg} \mathrm{BB}$ and $6.4 \mathrm{~g} / \mathrm{kg} \mathrm{BW}$. On the 19th day, blood glucose levels of mice group III, IV, V and VI had decreased blood glucose levels to normal with an average blood glucose level of 93-109.6 $\mathrm{mg} / \mathrm{dL}$.

\section{CONCLUSION}

Bungur leaves with $6.4 \mathrm{~g} / \mathrm{kg}$ dose has significantly different to the positive control group, so it has not been able to reduce MDA levels as well as positive control group. Bungur leaves with 3 variant doses can decrease blood glucose levels as well as positive control group.

\section{ACKNOWLEDGEMENT}

Thanks to LPPM Faculty of Pharmacy University of Pancasila which has helped financing in this research.

\section{ABBREVIATIONS}

BW: Body Weight; MDA: Malondialdehyde; DDY: Deutch Democratic Yokohama; TEP: tetraethoxypropane ; h: hour ; ANOVA: Analyze of Variance ; LSD: Least Significant Difference

\section{CONFLICT OF INTEREST}

The authors declare no conflict of interest.

\section{REFERENCES}

\footnotetext{
1. Allesio HM. Exercise-induced oxidative stress. Med Sci Sports Exerc. 1993:25:218-24

2. Ministry of Health of the Republic of Indonesia. Pharmaceutical care for diabetes mellitus disease. Issue 2. Jakarta: Directorate of Community Pharmacy and Clinic. DG of Pharmaceutical and Alkal. 2006:1-15.
} 
3. Szkudelski T. The mechanism of alloxan and streptozotocin action in B cells of the rat pancreas. Poland: Department of Animal Physiology and Biochemistry, University of Agriculture. 2001;50(6):537-46.

4. Sirwandanu RH. Effect of superoxidadismutase on changes in malondialdehyde levels in postoperative epidural hematoma patients. Dissertation, Faculty of Medicine, University of Indonesia, Jakarta, Indonesia. 2009.

5. Jati HS. Antioxidant effect in $70 \%$ ethanol extract of leaves (Syzygium polyanthum [Wight.] Walp.) In the liver Wistar male rats induced strain carbon tetrachloride (CCl4). Thesis, Faculty of Pharmacy University of Muhammadiyah, Surakarta, Indonesia. 2008.

6. Chougale AD, Panaskar SN, Gurao PM, Arvindeka AU. Optimization of alloxan dose is essential to induce stable diabetes for prolog periode. 2007.
7. Paravicini TM, Touyz RM. NADPH oxidase, reactive oxygen species, and hypertention. Diabetes Care. 2008;31(2):S170-80.

8. Hayashi TH, Maruyama R, Kasai K, Hattori S, Takasuga O, Hazeki K, et al. Ellagitanins from Lagerstroemia speciosa as activators of glucose transport in fat cells. Planta Med. 2002;68(2):173-5.

9. Weil CS. Tables for convenient calculation of median effective dose (LD50 or ED50) and instructions in their use. Biometrics. 1952;8(3)249-63.

10. Chisholm BM, et al. Pharmacology principle and practice. New York: McGraw-Hill Medical Publishing Division. 2008:644-57.

11. Gutteridge JM. Lipid peroxidation and antioxidants as biomarkers of tissue damage. Clin Chem. 1995;41(12):1819-28.

Article History: Submission Date : 12-12-2017 ; Revised Date : 28-01-2018; Acceptance Date : 15-03-2018.

Cite this article: Dewi RS, Rahayu L, Sandhiutami NMD, Sari OP. Effects of Bungur Leaves (Lagerstroemia speciose (L.) Pres.) on Malondialdehyde and Blood Glucose Levels in Hyperglycemic Mice. J Young Pharm. 2018;10(2)Suppl:s125-s127. 